J. Clin. Chem. Clin. Biochem.

Vol. 22, 1984, pp. 159-163

\title{
The Distribution of Zinc in Human Erythrocytes
}

\author{
By P. E. Gardiner
}

Institut für Angewandte Physikalische Chemie, Kernforschungsanlage Jülich GmbH, Jülich, Bundesrepublik Deutschland

\author{
H. Gessner, P. Brätter
}

Hahn-Meitner Institut für Kernforschung, Spurenelementforschung in der Biomedizin, Berlin (West)

\author{
M. Stoeppler and H.W. Nürnberg
}

Institut für Angewandte Physikalische Chemie, Kernforschungsanlage Jülich GmbH, Jülich, Bundesrepublik Deutschland

(Received September 6/November 30, 1983)

Summary: Gel permeation chromatography was used to fractionate zinc-bound constituents in haemolysates of human blood samples. The zinc content of the fractions was determined by electrothermal atomic absorption spectrometry. The zinc-containing enzyme, carbonic anhydrase, was identified by isoelectric focusing. A fraction of more than 0.9 of the zinc eluted from the column was bound to the carbonic anhydrase fraction. The fraction of zinc associated with unbound carbonic anhydrase was 0.786 of the total, and the remainder was found in a carbonic anhydrase-CO-haemoglobin complex.

\section{Die Verteilung von Zink in menschlichen Erythrocyten}

Zusammenfassung: Gelpermeations-Chromatographie wurde zur Fraktionierung von an Zink gebundenen Bestandteilen in Hämolysaten von menschlichen Blutproben angewandt. Der Zinkgehalt der Fraktionen wurde mit elektrothermaler Atomabsorptionsspektrometrie bestimmt. Das Zink enthaltende Enzym Carboanhydrase wurde durch isoelektrische Fokussierung identifiziert. Ein Anteil von über 0,9 des von der Säule eluierten Zinks befand sich in der Carboanhydrase-Fraktion. Der Anteil des an freier Carboanhydrase assoziierten Zinks betrug 0,786 von Gesamt-Zink, der Rest konnte einem Carboanhydrase-CO-Hämoglobinkomplex zugeordnet werden.

\section{Introduction}

Evidence that carbonic anhydrase, the most abundant protein after haemoglobin in the erythrocytes, contained zinc was provided by Keilin \& Mann (1) in 1940. Funakoshi \& Deutsch (2), using immunochemical techniques, were able to confirm this finding but in addition they reported that a small fraction of zinc was bound to the copper-containing protein, superoxide dismutase, called cytocuprein by the authors. More recently (3), it has been reported that human erythrocytes contain zinc protoporphyrin in cases of lead poisoning and iron deficiency.

Most of the reported studies on the isolation of zinccontaining constituents in erythrocytes have involved multi-step separation procedures, and require large volumes of blood. In the present study, we developed methods, requiring only small quantities of sample, for the fractionation, identification and determination of zinc-bound constituents in human erythrocytes. 


\section{Materials and Methods}

\section{Apparatus}

The equipment used for the fractionation of the blood haemolysates is described elsewhere (4).

The atomic absorption measurements were made with a PerkinElmer Model 5000 spectrophotometer equipped with a PerkinElmer HGA 400 heated graphite atomiser and a Perkin-Elmer Model AS-1 autosampler. The atomic absorption signals were recorded with a Perkin-Elmer Model 56 strip-chart recorder.

Isoelectric focusing of the column fractions was performed with a LKB system made up of the 1804 Ampholine PAG plates ( $\mathrm{pH}$ 3.5-9.5), Model 2117 Multiphor and Model 2103 power supply.

\section{Reagents}

The reagents for the fractionation procedure, and atomic absorption measurements are as previously described (4). The solutions used for electrofocusing are as recommended by the manfuacturer (5).

\section{Procedures}

\section{Purification of reagents and column}

The procedures for cleaning the columns, gel, buffer and UV cell were described in a previous publication (4).

\section{Sample collection and preparation}

Blood samples obtained by standard venipuncture were transferred to individual $10 \mathrm{ml}$ polyethylene tubes containing heparin. After centrifugation of the samples at $1000 \mathrm{~g}$ for $15 \mathrm{~min}$, the plasma was transferred to other tubes, the buffy coat was carefully pipetted from the top of the red blood cells, and the latter were resuspended in an equal volume of $9 \mathrm{~g} \cdot 1^{-1}$ saline at $4^{\circ} \mathrm{C}$. Resuspended red cells were centrifuged at $1000 \mathrm{~g}$ for $10 \mathrm{~min}$, supernatant removed by aspiration, and the whole procedure repeated twice more after additions of fresh saline. The washed blood cells $(100 \mu \mathrm{l})$ were lysed by diluting 20 -fold with deionised water. Samples and haemolysates were stored at $4{ }^{\circ} \mathrm{C}$.

\section{Chromatography of the haemolysates}

Haemolysate $(1 \mathrm{ml})$ was applied to the top of the gel, and after eluting about $170 \mathrm{ml}$ of buffer at a flow rate of $40 \mathrm{ml} \cdot \mathrm{h}^{-1}$, fifty $4.0 \mathrm{ml}$ fractions were collected in individual vials.

\section{Determination of zinc}

Standards $\left(0-40 \mu \mathrm{g} \mathrm{Zn} \cdot 1^{-1}\right)$ were prepared in $0.1 \mathrm{~mol} \cdot 1^{-1}$ Tris acetate buffer. For the total zinc determination, haemolysates were diluted $1: 20$ with $0.1 \mathrm{~mol} \cdot \mathrm{l}^{-1} \mathrm{HNO}_{3}$. Standards $(0-40 \mu \mathrm{g}$ $\mathrm{Zn} \cdot \mathrm{I}^{-1}$ ) were prepared in the same concentration of $\mathrm{HNO}_{3}$. Instrumental conditions for the analysis were as given in a previous publication (4).

\section{Carbonic anhydrase assay}

The enzyme activity was determined by a modified method of Mattenheimer \& DeBruin (6). The following modifications were made. A stock solution containing the Veronal/Veronal-Na buffer and the indicator was prepared by adding $400 \mathrm{ml}, 44 \mathrm{ml}$ and $18 \mathrm{ml}$ of the solutions, respectively. The incubation medium was made up of $1.3 \mathrm{ml}$ buffer/indicator mixture and $1 \mathrm{ml}$ peptone water. For the determination of carbonic anhydrase activity in the erythrocytes $20 \mu$ lof 1:100 diluted haemolysate were pipetted into the incubation medium. A similar determination in the column fractions required $100 \mu$ l of undiluted sample.

\section{Enzyme identification}

The procedure used for the isoelectric focusing experiments was as recommended by the manufacturer (5). Samples were applied to the gel surface using the filter paper method, and Coomassie Brillant Blue R 250 was used for staining the proteins.

\section{Results and Discussion}

The distribution of zinc, carbonic anhydrase catalytic activity, and the UV profile at $280 \mathrm{~nm}$ of a human blood haemolysate after gel permeation chromatography, is shown in figure 1 . There are three features to note in the above figure. First, the zinc chromatogram shows two distinct peaks, $\mathrm{A}$ and $\mathrm{B}$. Second, the distribution of the carbonic anhydrase activity is similar to that of zinc. Third, the peak observed in the UV profile which is due to haemoglobin appears at the same position as peak $B$.

In order to establish the molecular masses of the two zinc peaks, the column was calibrated with proteins of known molecular masses. The position of peak $A$ was found to correspond to that of a constituent with relative molecular mass of about 25000 . Estimates of the molecular mass of carbonic anhydrase given in the literature (7) vary between 26000 and 32000 . In addition to the similarities in molecular mass between the reported values and that obtained by calibration, the near coincidence of the carbonic anhydrase activity and peak A clearly indicates the association of zinc in this region with the enzyme. The slight difference in the maxima of the carbonic anhydrase activity and zinc peaks is due to the difference in the activity of the two major isozymes (I and II).

Over $98 \%$ of the total protein content in erythrocytes is haemoglobin, because of this overwhelming concentration, in relation to other proteins, it is possible that minor proteins may be non-specifically bound or trapped by haemoglobin-molecules and thus eluted together. However, Backman (8) has presented evidence to show that there is indeed an interaction between CO-haemoglobin ( $\mathrm{HbCO}$ ) and carbonic anhydrase. Furthermore, this interaction occurs between $\mathrm{HbCO}$ and one isozyme, carbonic anhydrase II. If a carbonic anhydrase- $\mathrm{HbCO}$ complex does exist then it will have a molecular mass of about 100000 . The position of a constituent with a molecular mass of 100000 is indicated by the arrow (fig. 1). The amount of zinc in this region is higher than the blank values which is an indication of a possible interaction.

A further examination of this association was carried out by applying a 1:3 instead of a 1:20 dilution of a haemolysate to the column. The separated fractions from both regions $A$ and $B$, together with a pure sample of carbonic anhydrase, were subjected to isoelectric focusing. As shown in figure 2, a carbonic anhydrase band (marked with arrow) is present in all fractions. Furthermore, the intensity of this band increased from region $B$ to $A$ in a similar pattern to the distributions of zinc and carbonic anhydrase activity. 


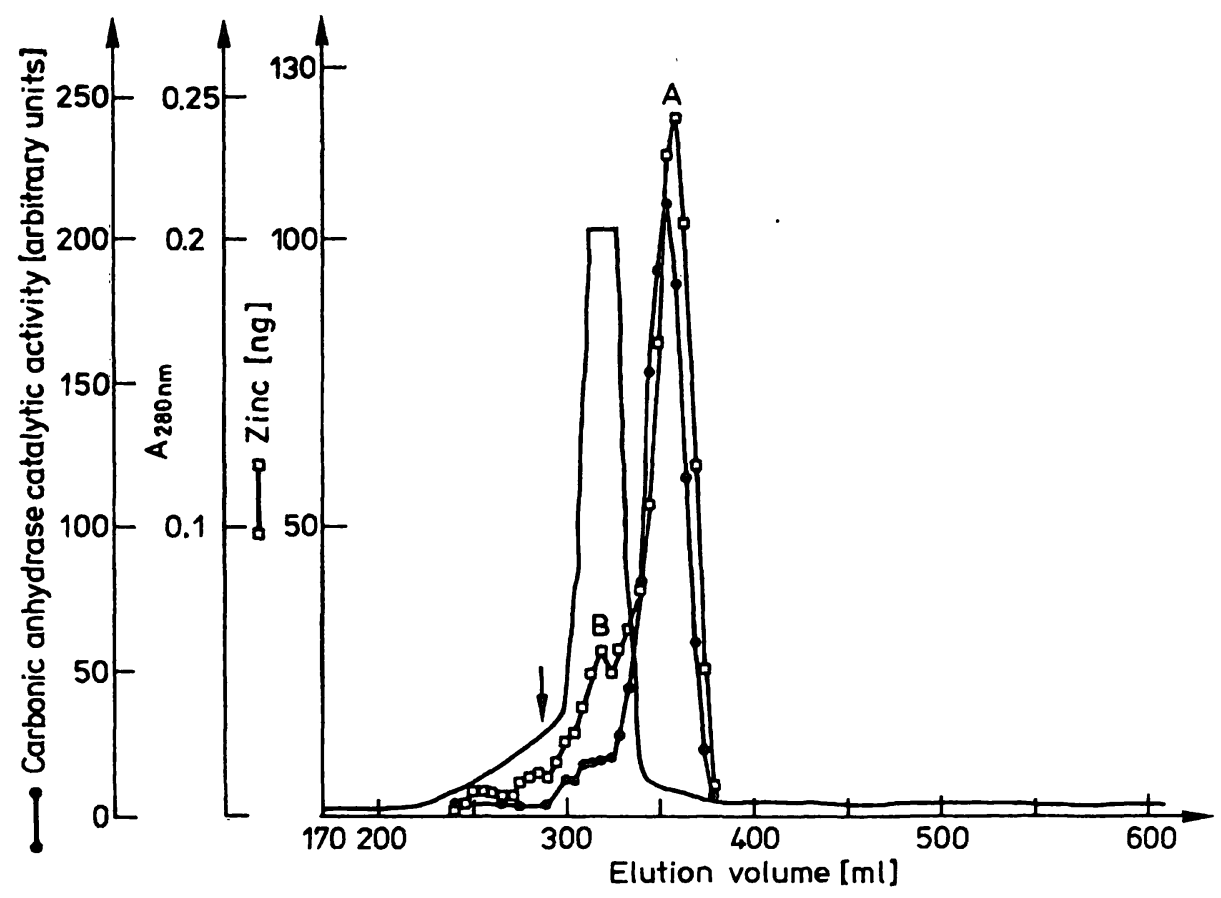

Fig. 1. Chromatography of human erythrocyte haemolysate on a Sephacryl S-300 column, showing elution profiles of zinc ( $\square$ ), carbonic anhydrase catalytic activity $(\Theta)$, and the $u . v$. absorbance at $280 \mathrm{~nm}(-)$. The samples were eluted with $0.1 \mathrm{~mol} \cdot 1^{-1}$ Tris-acetate buffer, $\mathrm{pH} 7.4$, at $4^{\circ} \mathrm{C}$ and a flow rate of $40 \mathrm{ml} \cdot \mathrm{h}^{-1}$. The letters $\mathrm{A}$ and $\mathrm{B}$ denote areas of suspected zinc binding.

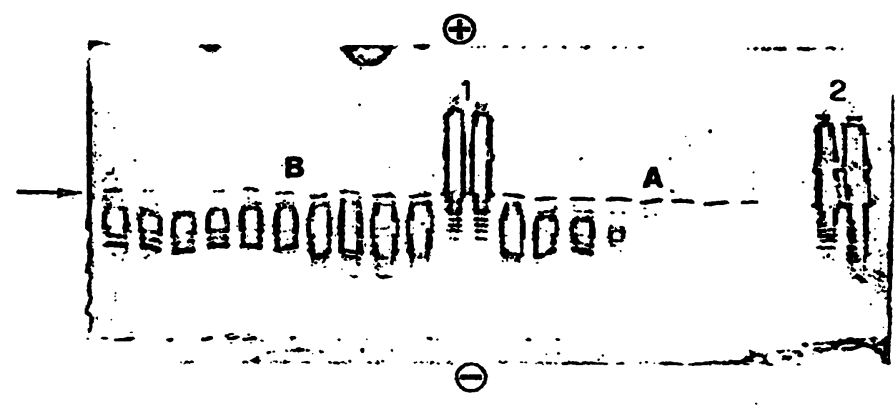

Fig. 2. Isoelectric focusing of proteins in the eluted fractions. The letters $A$ and $B$ denote regions of suspected zinc binding, similarly lettered as in figure 1 . The arrow shows the prominent carbonic anhydrase band, and 1 and 2 are samples of pure carbonic anhydrase enzyme.

In addition to isoelectric focusing, fractions were analysed for zinc and copper. The distribution of zinc and copper in these fractions is shown in figure 3 . The single arrow indicates the position of peak $B$ and the double arrows the position of a constituent with molecular mass of 100000 . Although there is evidence to suggest the existence of a carbonic anhydrase-HbCO complex with molecular mass of about 100000 , the isoelectric focusing experiments clearly show the presence of carbonic anhydrase in the re-

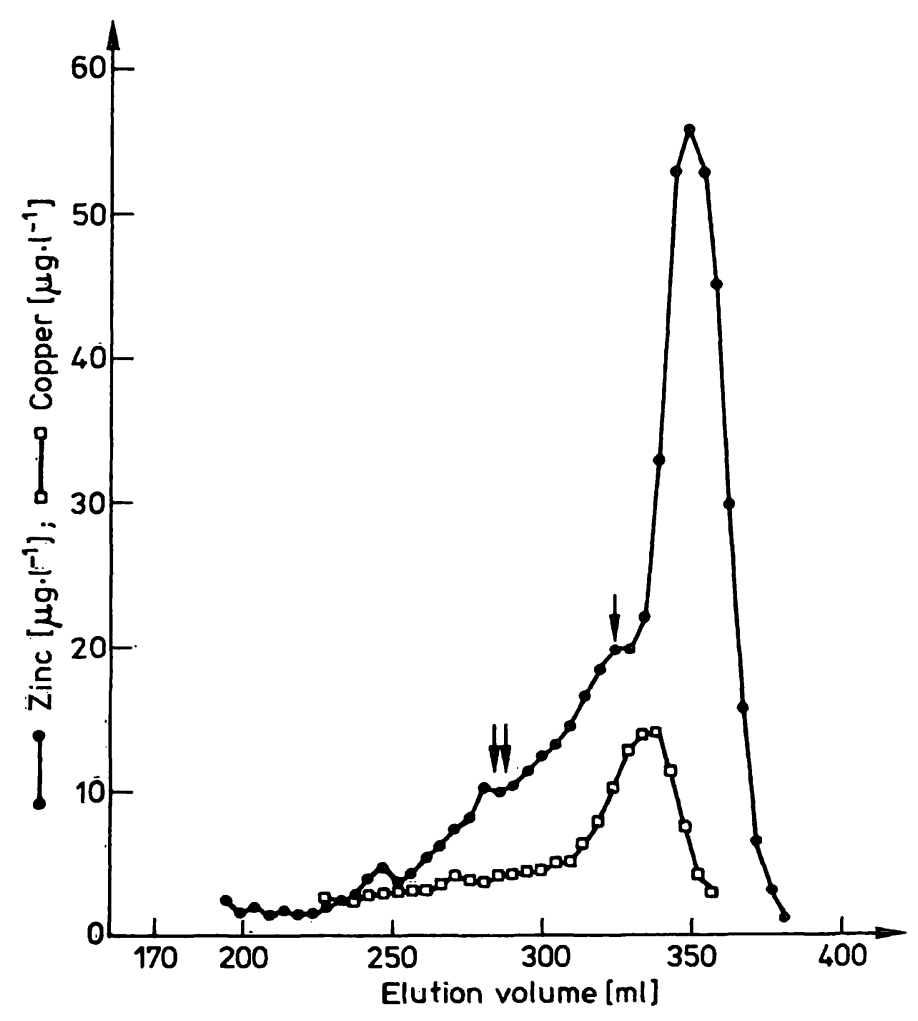

Fig. 3. The distributions of copper ( $(\square)$ and zinc (0). Before the fractions were analysed for zinc they were diluted five-fold with buffer. The single and double arrows denote areas in the chromatogram corresponding to molecular mass of 64000 and 100000 , respectively. 
gion containing the highest concentration of haemoglobin $\left(M_{\mathrm{r}}=64000\right)$. An explanation for this apparent discrepancy is that in permeation chromatography separation is achieved not strictly according to molecular mass but Stokes radius. It is therefore possible that the difference between the Stokes radius of the complex and haemoglobin is small and hence the two constituents cannot be resolved on the column used. The formation of dimers by the carbonic anhydrase could also explain the occurrence of this zinc peak. However, no such formation has as yet been reported for human carbonic anhydrase (9).

Examination of previously published methods for the isolation of carbonic anhydrase showed that the first step in the procedures developed had involved the removal of haemoglobin from the haemolysate. Haemoglobin was either destroyed by denaturation and precipitation with a mixture of ethanol, water and chloroform, or separated by chromatography. In the first case, the carbonic anhydrase-HbCO complex was destroyed and in the second the fraction containing the complex was discarded. The presence of this complex was therefore not observed by previous workers for the above reasons. The results presented here, together with the work of Backman (8), does provide evidence of an association between carbonic anhydrase and CO-haemoglobin.

In contrast to zinc, only one major copper peak is present in human erythrocytes (fig. 3). The difference in the elution volume between the zinc associated with unbound carbonic anhydrase (peak A) and the copper peak is about $14 \mathrm{ml}$. This copper-containing constituent was found to have a molecular mass of about 30000 . This value is in good agreement with the literature value of 34000 obtained for the zinc- and copper-containing enzyme erythrocuprein or $\mathrm{Cu}_{2} \mathrm{Zn}_{2}$ superoxide dismutase. According to $\mathrm{Fu}$ nakoshi \& Deutsch (2) this enzyme accounts for a fraction of about 0.025 of the total zinc in erythrocytes. A fraction of more than 0.9 of the copper in erythrocytes is associated with this enzyme. This finding is in good agreement with the work of Gärtner \& Weser (10) who found that a fraction of about 0.95 of the copper in erythrocytes was bound to $\mathrm{Cu}_{2} \mathrm{Zn}_{2}$ superoxide dismutase. In the study, no clear association between zinc and $\mathrm{Cu}_{2} \mathrm{Zn}_{2}$ superoxide dismutase was found because both enzymes were not completely resolved by the fractionation procedure. However, the fraction of zinc bound to this fraction will certainly be less than 0.1 of the total present in the erythrocytes, assuming that similar amounts of zinc and copper are bound to the enzyme.
From the foregoing discussion it can be deduced that nearly all of the zinc in erythrocytes is bound to carbonic anhydrase. However, the zinc associated with this enzyme can be divided into two parts i.e. zinc associated with unbound carbonic anhydrase, and that associated with carbonic anhydrase bound to CO-haemoglobin. In order to estimate the relative amounts of zinc in these two fractions, blood haemolysates from ten healthy adults were examined (tab. 1). It was found that a fraction of $0.786 \pm$ 0.045 (mean \pm 1 SD) of the zinc recovered from the column was associated with unbound carbonic anhydrase and a fraction of $0.214 \pm 0.045$ was in the form of the complex.

Tab. 1. Distribution of zinc in human blood haemolysates.

\begin{tabular}{lllll}
\hline Subject & $\begin{array}{l}\text { Zinc asso- } \\
\text { ciated with } \\
\text { bound } \\
\text { carbonic } \\
\text { anhydrase } \\
\text { (ng) }\end{array}$ & $\begin{array}{l}\text { Fraction } \\
\text { of total } \\
\text { zinc } \\
\text { recovered }\end{array}$ & $\begin{array}{l}\text { Zinc asso- } \\
\text { ciated with } \\
\text { unbound } \\
\text { carbonic } \\
\text { anhydrase } \\
\text { (ng) }\end{array}$ & $\begin{array}{l}\text { Fraction } \\
\text { of total } \\
\text { zinc } \\
\text { recovered }\end{array}$ \\
& & & & \\
\hline & & & & \\
K. L. & 187.9 & 0.245 & 577.6 & 0.755 \\
B. A. & 111.6 & 0.196 & 457.9 & 0.804 \\
R.A. & 91.0 & 0.152 & 506.3 & 0.848 \\
R. O. & 123.8 & 0.203 & 489.5 & 0.797 \\
B. I. & 96.9 & 0.188 & 417.7 & 0.812 \\
G. U. & 126.0 & 0.220 & 445.6 & 0.780 \\
W. I. & 98.6 & 0.150 & 558.5 & 0.850 \\
K. E. & 162.6 & 0.282 & 415.1 & 0.718 \\
M. O. & 165.1 & 0.232 & 545.0 & 0.768 \\
G. A. & 225.4 & 0.268 & 616.1 & 0.732 \\
Mean & 138.9 & 0.214 & 502.6 & 0.786 \\
\pm 1 SD & \pm 44.7 & \pm 0.045 & \pm 69.8 & \pm 0.045 \\
n= 10 & & & & \\
\hline
\end{tabular}

According to Backman (8) the difference in the ability of the two isozymes to bind $\mathrm{HbCO}$ is an indication that they may have different physiological functions. In fact, it has been observed that under certain pathological conditions only one isozyme shows quantitative changes (9). It is also possible that only one of these isozymes is affected in the development of zinc deficiency. Therefore the determination of the amount of both major isozymes in erythrocytes, in addition to using the methods developed here, provides an better way of studying these changes. 


\section{References}

1. Keilin, D. \& Mann, T. (1940) Biochem. J. 34, 1163-1176.

2. Funakoshi, S. \& Deutsch, H. F. (1970) J. Biol. Chem. 245, 2852-2856.

3. Chisolm, Jr., T. T. \& Brown, D. H. (1979) Biochem. Med. $22,214-237$.

4. Gardiner, P. E., Rösick, E., Rösick, U., Brätter, P. \& Kynast, G. (1982) Clin. Chim. Acta 120, 103-111.

5. LKB Application Note 250. LKB-Produkter AB. Bromma, Sweden, December, 1977.
6.' Mattenheimer, H. \& DeBruin, H. (1962) Anal. Biochem. 4, 222-230.

7. Rickli, E. E., Ghazanfer, A. S., Gibbons, B. H. \& Edsall, J. T. (1964) J. Biol. Chem. 239, 1065-1078.

8. Backman, L. (1981) Eur. J. Biochem. 120, 257-261.

9. Linkskog, S., Henderson, L. E., Kannan, K. K., Liljas, A., Nyman, P. O. \& Strandberg, B. (1977) The Enzymes, Vol. 5, Academic Press New York.

10. Gärtner, A. \& Weser, U. (1983) FEBS Letters 155, 15-18.
Dr. P. E. Gardiner

Institut für Angewandte Physikalische Chemie

Kernforschungsanlage Jülich GmbH

Postfach 1913

D-5170 Jülich 
.

. 